\title{
Aktivitas Ekstrak Daun Salam (Syzygium Polyanthum) sebagai Antirheumatoid Artritis pada Tikus yang Diinduksi Complete Freund's Adjuvants (CFA)
}

\section{(Antirheumatoid Arthritis Activity of Salam (Syzygium polyanthum) Leaf Extract to Mice Induced by Complete Freund's Adjuvants (CFA))}

\author{
Sitti Amirah ${ }^{1 *}$, Aulia Wati ${ }^{1}$, Bayu Putra ${ }^{1}$, Fitri A. Walani ${ }^{1}$ \\ ${ }^{I}$ Program Studi Sarjana Farmasi, Fakultas Farmasi, Universitas Muslim Indonesia, Makassar, Indonesia . \\ E-mail: sitti.amirah@umi.ac.id
}

Article Info:

Received: 2 Desember 2019

in revised form: 21 Januari 2020

Accepted: 20 Februari 2020

Available Online: 02 Maret 2020

Keywords:

Arthritis rheumatoid Complete Freund's Adjuvant

Syzygium polyanthum leaf

Corresponding Author:

Sitti Amirah

Program Studi Sarjana Farmasi

Fakultas Farmasi

Universitas Muslim Indonesia

Makassar

90231

Indonesia

email: sitti.amirah@umi.ac.id

\begin{abstract}
Rheumatoid arthritis is a chronic autoimmune disease, which is characterized by inflammation and degradation of the joints and cartilages. Rheumatoid therapy is currently using immunosuppressant drugs, nonsteroidal anti-inflammatory drugs and corticosteroids. Treatment of chronic rheumatoid can trigger side effects. Syzygium polyanthum leaves contain alkaloid compounds, flavonoids, saponins, tannins and essential oils consist of citral and eugenol which are thought to be potential as antirheumatoid. This study aims to determine the effect antirheumatoid arthritis and effective dose of ethanol extracts of Syzygium polyanthum leaf. This study used 15 male rats. Treatment started by measuring foot volume using a pletismometer and then inducting CFA intraplantary as much as 0,1 $\mathrm{mL}$ on day 1 and left until day $16^{\text {th }}$. On the day $17^{\text {th }}$ a foot volume and arthritis index was measured and then treated until the day $30^{\text {th }}$. The animals were divided into 5 groups: negative control (Na. CMC 1\%), positive control (methylprednisolone dose $1.646 \mathrm{mg} / \mathrm{kg} \mathrm{BW}$ ), ethanol extractof Syzygium polyanthum leaf at a dose of $75 \mathrm{mg} / \mathrm{kg}, 150 \mathrm{mg} / \mathrm{kg}$ and $300 \mathrm{mg} / \mathrm{kg}$. On the day $31^{\text {st }}$, foot volume and arthritis index measurements were taken again. The results showed a decrease in foot volume and arthritis index after given of the extract. Foot volume difference data were analyzed using the One Way Anova test followed by the Post Hoc LSD test. The difference between the arthritis index data was analyzed using Kruskal-Wallis followed by the Mann-Whitney test. Statistical results show that positive control has the same effect as extract ( $P>0.05)$. Based on the results of statistical analysis of inflammation of the foot volume and the arthritis index shows that the ethanol extract of Syzygium polyanthum leaf had an effect as an antirheumatoid arthritis.
\end{abstract} This open access article is distributed under a Creative Commons Attribution (CC-BY-NC-SA) 4.0 International license.

How to cite (APA $6^{\text {th }}$ Style):

Amirah, S., Wati, A., Putra, B., Walani, F. A. (2020). Aktivitas Ekstrak Daun Salam (Syzygium Polyanthum) Sebagai Antirheumatoid Artritis Pada Tikus yang Diinduksi Complete Freund's Adjuvants (CFA). Jurnal Farmasi Galenika :Galenika Journal of Pharmacy (e-Journal), 6(1), 77-83. doi:10.22487/j24428744.2020.v6.i1.14581 


\section{ABSTRAK}

Rheumatoid artritis merupakan penyakit autoimun yang bersifat kronis, yang ditandai dengan inflamasi dan degradasi pada sendi serta kartilago. Terapi rheumatoid saat ini menggunakan obat-obat imunosupresan, antiinflamasi nonsteroid dan kortikosteroid. Pengobatan rheumatoid yang bersifat kronik dapat memicu munculnya berbagai efek samping yang tidak dikehendaki. Daun salam mengandung senyawa alkaloid, flavonoid, saponin, tanin serta minyak atsiri yang terdiri dari sitral dan eugenol yang di duga berpotensi sebagai antirheumatoid. Penelitian ini bertujuan untuk menentukan efek dan dosis efektif ekstrak etanol daun salam sebagai antirheumatoid artritis. Penelitian ini menggunakan 15 ekor tikus jantan. Perlakuan dimulai dengan mengukur volume kaki menggunakan pletismometer kemudia menginduksi hewan uji dengan CFA $0,1 \mathrm{ml}$ secara intraplantar pada hari ke-1 dan dibiarkan sampai hari ke-16. Pada hari ke 17 dilakukan pengukuran volume kaki dan indeks artritis kemudian diberikan perlakuan sampai hari ke-30. Hewan uji dibagi dalam 5 kelompok yaitu kontrol negatif (Na. CMC 1\%), kontrol positif (metilprednisolon dosis 1,646 mg/kg BB), ekstrak etanol daun salam dengan dosis $75 \mathrm{mg} / \mathrm{KgBB}, 150 \mathrm{mg} / \mathrm{KgBB}$ dan $300 \mathrm{mg} / \mathrm{KgBB}$. Pada hari ke-31 kembali dilakukan pengukuran volume kaki dan indeks artritis. Hasil penelitian menunjukkan adanya penurunan volume kaki dan indeks artritis setelah pemberian ekstrak. Data selisih volume kaki dianalisis menggunakan uji One Way Anova yang dilanjutkan dengan Post Hoc uji LSD. Selanjutnya, data selisih indeks arthritis dianalisis dengan menggunakan Kruskal-Wallis yang dilanjutkan dengan uji Mann-Whitney. Hasil statistik menunjukkan bahwa kontrol positif memiliki efek yang sama dengan ekstrak $(\mathrm{P}>0,05)$. Berdasarkan hasil analisa statistik volume kaki radang dan indeks artitis menunjukkan bahwa ekstrak etanol daun salam memiliki efek sebagai antirheumatoid artritis.

Kata kunci: Rheumatoid artritis, Complete Freund's Adjuvant, daun salam, Syzygium polyanthum

\section{PENDAHULUAN}

Rheumatoid arthritis adalah suatu penyakit yang ditandai dengan inflamasi kronik dan menyebabkan degenerasi jaringan ikat. Inflamasi terjadi secara terus-menerus terutama pada organ sinovium dan menyebar ke struktur sendi disekitarnya seperti tulang rawan, kapsul fibrosa sendi, legamen dan tendon. Inflamasi ditandai dengan penimbunan sel darah putih, pengaktifan komplemen, fagositosis ekstensif dan pembentukan jaringan granular. Pada inflamasi kronis, membrane sinovial mengalami hipertrofi dan menebal sehingga menyembat aliran darah dan lebih lanjut menstimulasi nekrosis sel dan respons inflamasi yang disebut panus. Panus menyebar ke seluruh sendi sehingga menyebabkan inflamasi dan pembentukan jaringan parut lebih lanjut. Proses ini secara lambat merusak tulang dan menimbulkan nyeri hebat serta deformitas (Corwin \& Elizabeth, 2009).

Hasil Riset Kesehatan Dasar 2013, menunjukkan prevalensi penyakit sendi berdasarkan gejala atau diagnosis tenaga kesehatan sebesar $24,7 \%$. Prevalensi penyakit sendi ini meningkat dengan semakin bertambahnya usia yaitu usia 25-34 tahun sebesar 16,1\%, 35-44 tahun sebesar 26,9\%, dan 45-54 tahun sebesar 37,25\%. Perempuan memiliki resiko lebih besar dari pada laki-laki (Riskesdas, 2013).

Terapi yang sering digunakan untuk rheumatoid arthritis adalah obat golongan DMARD (disease modifying anti rheumatic drugs) seperti metotreksat, leflunomida, dan sulfasalazin. Obat golongan ini bersifat antiradang yang kuat. Senyawa-senyawa ini sering dikombinasikan dengan obat golongan antiinflamasi nonsteroid maupun golongan kortikosteroid untuk memperkuat efeknya, namun efek samping yang ditimbulkan dari penggunaan obat-obat tersebut cukup berbahaya, yaitu dapat menyebabkan pendarahan pada gastrointestinal, mual, dispepsia, gangguan fungsi ginjal (Dipiro et al, 2009). Hal inilah yang mendorong peneliti untuk melakukan pencarian kandidat obat antireumatoid dari bahan alam dengan efek samping yang relatif lebih kecil. Salah satu tanaman yang banyak digunakan sebagai obat tradisional adalah daun salam. Daun salam mengandung senyawa alkaloid, flavonoid, saponin, tanin serta minyak atsiri yang terdiri dari sitral dan eugenol. Beberapa senyawa kimia yang terdapat pada daun salam diduga memiliki potensi sebagai antireumatoid (Widyaningrum, 2011). 
Jenis flavonoid yang diketahui berperan dalam aktivitas antiinflamasi, senyawa ini memiliki mekanisme antiinflamasi dengan menghambat enzim siklooksigenase sehingga tidak membentuk mediator inflamasi (Sativa et al., 2014). Penelitian sebelumnya menunjukkan bahwa daun salam memiliki efek sebagai antiinflamasi, dimana dosis $125 \mathrm{mg} / \mathrm{kgBB}$ memiliki efek penurunan volume edema kaki tikus yang paling optimal (Khatimah, 2015). Hal inilah yang mendorong peneliti untuk melakukan penelitian lebih lanjut terkait potensi efek antireumatoid dari daun salam.

\section{METODE PENELITIAN}

\section{Alat dan Bahan}

Alat-alat yang digunakan dalam penelitian ini yaitu labu ukur (pyrex), kanula tikus, spoit (Disposable syringe), plestimometer (Panlab), timbangan analitik (Ohaus), timbangan hewan (Ohaus), seperangkat alat maserasi, dan seperangkat alat rotavapor (IKA). Bahan yang digunakan dalam penelitian ini yaitu Complete Freund's Adjuvant, aquades, ekstrak daun salam (Syzygium polyanthum (Weight) Walph.), etanol 70\%, Na-CMC 1\% b/v, Metilprednisolon.

\section{Metode}

\section{Pengambilan dan Pengolahan Sampel}

Daun salam (Syzygium polyanthum (Weight) Walph.) diambil di Kota Makassar. Daun salam yang telah diambil kemudian dicuci menggunakan air yang mengalir dan dikeringkan tanpa sinar matahari. Setelah itu dipotong-potong kecil lalu diserbukkan.

\section{Pembuatan Ekstrak Daun salam (Syzygium polyanthum (Weight) Walph.)}

Serbuk simplisia daun salam ditimbang sebanyak 500 gram, dimasukkan dalam bejana maserasi (toples), kemudian ditambahkan etanol 70\% sampai serbuk simplisia seluruhnya terendam. Dibiarkan selama $1 \times 24$ jam, sambil sekali-kali diaduk selama 6 jam, dan dibiarkan selama 18 jam pada suhu kamar dan terlindung dari sinar matahari langsung. Setelah itu dilakukan penyaringan dan dilakukan remaserasi sebanyak 2 kali. Filtrat yang diperoleh ditampung kemudian diuapkan dengan menggunakan rotavapor sehingga diperoleh ekstrak kental dari daun salam (Depkes RI, 2010).

\section{Penyiapan Hewan Uji}

Penelitian ini menggunakan 15 ekor hewan coba yang diperoleh dari peternakan hewan Surabaya. Hewan coba terlebih dahulu diadaptasikan selama \pm 7 hari didalam kadang Laboratorium Farmakologi Fakultas Farmasi Universitas Muslim. Hewan coba yang sehat dan memenuhi syarat berat badan selanjutnya akan digunakan dalam penelitian.

\section{Pelakuan Hewan coba}

Hewan coba yang memenuhi persyaratan selanjutnya diukur volume kaki menggunakan plestismometer. Pada hari ke-1, hewan uji diinduksi dengan CFA $0,1 \mathrm{~mL}$ secara intraplantar dan dibiarkan sampai hari ke-16. Pada hari ke-17 dilakukan pengukuran volume kaki kemudian hewan uji dibagi menjadi 5 kelompok sebagai berikut:

a. Kelompok 1 diberikan Na.CMC sebagai kontrol negatif.

b. Kelompok 2 diberikan suspensi metilprednisolon $0,267 \mathrm{mg} / \mathrm{KgBB}$ sebagai kontrol positif.

c. Kelompok 3 diberikan ekstrak etanol daun salam dengan dosis ekstrak $75 \mathrm{mg} / \mathrm{KgBB}$.

d. Kelompok 4 diberikan ekstrak etanol daun salam dengan dosis ekstrak $150 \mathrm{mg} / \mathrm{KgBB}$.

e. Kelompok 4 diberikan ekstrak etanol daun salam dengan dosis ekstrak 300 mg/KgBB.

Pemberian ekstrak dilakukan sampai hari ke-30 secara oral. Dilakukan kembali pengukuran volume kaki pada hari ke-31 (Mulyaningsih \& Darmawan, 2006; Asad et al, 2007). 


\section{Pengukuran Indeks Arthritis}

Pengukuran indeks arthritis dilakukan pada hari ke-17 dan ke-31 berdasarkan pada tabel 1 (Mulyaningsih \& Darmawan, 2006).

Tabel 1. Parameter pengamatan indeks arthritis (smith, 2000).

\begin{tabular}{lll}
\hline No & Gejala Artritis yang Nampak pada tikus & Skor \\
\hline 1 & Bengkak dan merah pada 1 jari kaki & 0,25 \\
\hline 2 & Bengkak dan merah sedikitnya 2 jari kaki & 0,50 \\
\hline 3 & Bengkak pada telapak kaki & 0,75 \\
\hline 4 & $\begin{array}{l}\text { Bengkak dan merah pada jari kaki dan perubahan bentuk } \\
\text { pada telapak kaki }\end{array}$ & 1,00 \\
\hline 5 & Bengkak dan merah pada jari kaki dan telapak kaki & 1,25 \\
\hline 6 & $\begin{array}{l}\text { Bengkak dan merah pada jari kaki dan sedikit bengkak } \\
\text { pada sebagian telapak dan pergelangan kaki. }\end{array}$ & 1,50 \\
\hline 7 & $\begin{array}{l}\text { Bengkak dan merah pada jari dan telapak kaki serta } \\
\text { bengkak pada seluruh telapak dan pergelangan tangan }\end{array}$ \\
\hline 8 & $\begin{array}{l}\text { Bengkak dan merah pada jari kaki, telapak dan pergelangan } \\
\text { kaki }\end{array}$ & 2,00 \\
\hline
\end{tabular}

Setiap tikus pada masing-masing kelompok diamati indeks artritisnya dimana tikus dinyatakan rematoid artritis jika memiliki indeks arthritis $>1$.

\section{HASIL DAN PEMBAHASAN}

\section{Pengukuran indeks arthritis}

Hasil pengukuran volume kaki awal, induksi dan terapi dapat dilihat pada tabel 2 dibawah ini:

Tabel 2. Rata-Rata Volume Kaki Awal, Induksi Dan Terapi

\begin{tabular}{lccc}
\hline \multirow{2}{*}{ Kelompok Perlakuan } & \multicolumn{3}{c}{ Rata-rata volume kaki (mL) } \\
\cline { 2 - 4 } & Awal \pm SD & Induksi \pm SD & Terapi \pm SD \\
\hline $\begin{array}{l}\text { Kelompok I kontrol negatif } \\
\text { (Na.CMC 1\%) }\end{array}$ & $0,27 \pm 0,01$ & $0,85 \pm 0,13$ & $0,82 \pm 0,58$ \\
$\begin{array}{l}\text { Kelompok II Kontrol positif } \\
\text { (Metilprednisolon) }\end{array}$ & $0,33 \pm 0,04$ & $0,78 \pm 0,06$ & $0,37 \pm 0,05$ \\
$\begin{array}{l}\text { Kelompok III } \\
\text { EEDS 75 mg/KgBB }\end{array}$ & $0,30 \pm 0,01$ & $0,79 \pm 0,02$ & $0,37 \pm 0,03$ \\
$\begin{array}{l}\text { Kelompok IV } \\
\text { EEDS 150 mg/KgBB }\end{array}$ & $0,30 \pm 0,03$ & $0,81 \pm 0,01$ & $0,40 \pm 0,05$ \\
Kelompok V & $0,32 \pm 0,02$ & $0,78 \pm 0,07$ & $0,38 \pm 0,03$ \\
EEDS 300 mg/KgBB & & & \\
\hline
\end{tabular}

Keterangan:

EEDS $\quad$ : Ekstrak Etanol Daun Salam

Dari tabel 2 dapat dilihat bahwa terjadi peningkatan volume kaki pada semua kelompok setelah diinduksi CFA. Peningkatan volume kaki menunjukkan kemampuan CFA untuk menginduksi inflamasi. Pemberian CFA akan menstimulasi fagositosis, sekresi sitokin oleh fagositosis mononuklear, sehingga berbagai jenis sitokin proinflamasi seperti TNF- $\alpha$, IL-1, IL-6, IL-8, PGE-2, NO, MMP dan mediator lainnya akan dilepaskan (Fajrin, Khatib \& Susilo, 2013). TNF- $\alpha$ bekerja sinergis dengan Receptor Activator Of Nuclear Factor $-k \beta$ Ligant (RANKL) dan menyebabkan 
osteoklastogenesis melalui precursor osteoklas. Receptor Activator Of Nuclear Factor-k $\beta$ (RANK) akan memicu diferensiasi sel menjadi osteoklas. TNF- $\alpha$ juga dapat mengembangkan arthritis inflamasi kronis, dengan hiperplasia sinovium, infiltrat inflamasi di bagian sendi, pembentukkan pannus dan kartilago serta destruksi tulang. Selain itu juga terdapat IL-1 dan IL-6 yang ikut terlibat dalam patofisiologi rheumatoid artritis (Plenge et al., 2007).

Dari tabel 2 juga terlihat adanya penurunan volume kaki pada semua kelompok perlakukan kecuali kontrol negatif. Besarnya rata-rata penurunan volume kaki dapat dilihat pada tabel 3. Penurunan terbesar terlihat pada kelompok EEDS $75 \mathrm{mg} / \mathrm{KgBB}$ dan metilprednisolon. Hal ini menunjukkan bahwa ekstrak etanol daun salam memiliki efek sebagai antiinflamasi.

Tabel 3. Persen rata-rata penurunan volume kaki setelah terapi

\begin{tabular}{cc}
\hline Kelompok perlakuan & \% Penurunan \\
\hline Kelompok I kontrol negatif (Na. CMC 1\%) & 4,71 \\
Kelompok II kontrol positif (Metilprednisolon) & 52,09 \\
Kelompok III EEDS $75 \mathrm{mg} / \mathrm{KgBB}$ & 52,93 \\
Kelompok IV EEDS $150 \mathrm{mg} / \mathrm{KgBB}$ & 50,84 \\
Kelompok V EEDS $300 \mathrm{mg} / \mathrm{KgBB}$ & 51,18 \\
\hline
\end{tabular}

Selanjutnya, hasil analisis statistik One-Way Anova data persen penurunan volume kaki menunjukkan adanya perbedaan antara tiap kelompok perlakuan $(\mathrm{p}<0,05)$. Tidak ada perbedaan antara kelompok kontrol positif (Metilprednisolon) dengan kelompok ekstrak. Hal ini berarti kelompok ekstrak uji dengan kelompok kontrol positif memiliki efek yang sama dalam menurunkan volume kaki tikus.

\section{Hasil pengukuran indeks artritis}

Hasil pengukuran indeks artritis setelah induksi dan terapi dapat dilihat pada tabel 5 dibawah ini:

Tabel 4. Rata-rata indeks artritis induksi dan terapi

\begin{tabular}{lcc}
\hline \multirow{2}{*}{ Kelompok Perlakuan } & \multicolumn{2}{c}{ Rata-rata volume kaki (mL) } \\
\cline { 2 - 3 } & Induksi \pm SD & Terapi \pm SD \\
\hline Kelompok I (Na.CMC 1\%) & $2,67 \pm 0,58$ & $2,67 \pm 0,58$ \\
Kelompok II (Metilprednisolon) & $2,00 \pm 0,00$ & $0,67 \pm 0,00$ \\
Kelompok III (EEDS 75 mg/KgBB) & $2,67 \pm 0,58$ & $0,67 \pm 0,00$ \\
Kelompok IV (EEDS 150 mg/KgBB) & $2,33 \pm 0,58$ & $0,67 \pm 0,58$ \\
Kelompok V (EEDS 300 mg/KgBB) & $2,33 \pm 0,58$ & $0,67 \pm 0,58$ \\
\hline
\end{tabular}

Keterangan:

EEDS : Ekstrak Etanol Daun Salam

Tabel 4 menunjukkan adanya penurunan indeks artritis pada semua kelompok uji kecuali kelompok kontrol negatif. Kelompok EEDS $75 \mathrm{mg} / \mathrm{KgBB}$ menunjukkan penurunan indeks artritis terbesar. Hasil statistik selisih indeks artritis antara induski dan terapi menggunakan uji Kruskal-Wallis menunjukkan adanya perbedaan antara kelompok perlakuan ( $<<0,05)$. Hasil uji Mann-Whitney menunjukkan tidak ada perbedaan antara kelompok kontrol positif dengan kelompok ekstrak uji. Hal ini berarti kelompok 
kontrol positif (Metilprednisolon) memiliki efek yang sama dengna kelompok kontrol uji dalam menurunkan indeks artritis pada hewan uji.

Kemampuan daun salam sebagai antirheumatoid artritis diduga karena adanya kandungan golongan senyawa flavonoid yang diketahui berperan dalam aktivitas antiinflamasi, senyawa ini memiliki mekanisme antiinflamasi dengan menghambat enzim siklooksigenase sehingga menghambat pembentukan sitokin proinflamasi (Sativa, Sulastri \& Yuliet, 2014). Selain itu flavonoid juga berperan dalam aktivasi sistem imun yang dapat berefek sebagai antirheumatoid arthritis (Scheet \& Ian, 2011).

\section{KESIMPULAN}

Ekstrak etanol daun salam Syzygium polyanthum (Weight) Walph.h.) dengan dosis $75 \mathrm{mg} / \mathrm{KgBB}$ efektif sebagai antirheumatoid artritis terhadap tikus jantan yang diinduksi Complete Freund's Adjuvant.

\section{UCAPAN TERIMAKASIH}

Terima kasih penulis sampaikan kepada Universitas Muslim Indonesia atas dukungannya baik materil maupun nonmateril sehingga penelitian ini dapat terlaksana.

\section{DAFTAR PUSTAKA}

Asad, M., Prasad, K., Thomas, L., \& Kamath, J. V. (2007). Evaluation of Analgesics and AntiInflammatory Activiyt of Sudard, A Poly-Herbal Formulation, Iranian Journal of Pharmacology \& Therapeutics, 6(1), 71-75.

Corwin., Elizabeth, J. (2009). Handbook of pathophysiology 3th edition. Lippincort $\quad$ Williams \& Wilkins: Philadelphia.

Departemen Kesehatan Republik Indonesia. (2010). Farmakope Herbal. Jakarta: Departemen Kesehatan Republik Indonesia.

Dipiro, J. T., Wells, G. B., Schwinghammer, L. T., dan Dipiro, V, C 2009, Pharmacotherapy Handbook Seven Edition, The McGraw-Hill Companies: United States of America.

Kementerian Kesehatan Republik Indonesia. (2013). Riset Kesehatan Dasar 2013. Jakarta: Badan Penelitian dan Pengembangan.

Khatimah, K. (2015). Uji Efek Antiinflamasi Ekstrak Etanol Daun Salam ～(Syzygium polyanthum (wight) walp) Terhadap Tikus (Rattus norvegicus) Jantan yang Diinduksi Karagen. (Unpublished Undergraduate Thesis). Fakultas Farmasi Universitas Muslim Indonesia. Indonesia.

Mulyaningsih, S., \& Darmawan, E. (2006). Efek Anti Artritis Pisang Ambon (Musa paradisiaca sapientum L) dan lidah buaya (Aloe Vera L) terhadapa Adjuvant-Induces Arthritic pada tikus. Biodiversitas, 7(3), 273-277.

Plenge, R., Cotsapas, C., Davies, L., Price, A., Bakker, P., Maller, J., Pe'er, I., Burtt, N., Blumenstiel, B., DeFelice, M., Parkin, M., Barry, R., Winslow, W., Healy, C., Graham, R., Neale, B., Izmailova, E., Roubenoff, R., Parker, A., \& Altshuler, D. (2007). Two independent alleles at 6q23 associated with risk of rheumatoid arthritis. Nature Genetics, 39, 1477-1482. https://doi.org/10.1038/ng.2007.27

Sativa, O., Sulstri, E., \& Yuliet. (2014). Uji aktivitas antiinflamasi gel ekstrak buah kaktus (Opuntia elatior Mill.) pada tikus (Rattus norvegicus) yang diinduksi lamda karagen. Jurnal of Science and Technology, 3(2), 79-94. 
Smith, F. (2000). Picrorhiza Scrophulariiflora from Traditional Use to Immunomodulatory, (Dissertation). Rijksuniversiteit Utrech. Utrecht.

Widyaningrum. (2011). Kitab Tanaman Obat Nusantara. Yogyakarta: Penerbit Medpress. 